Ken Peters PhD

Visiting Professor at Florida International University

School of Public \& International Affairs

6.24 .19

\title{
Commercial real estate: How Macro lending policies create Microeconomic spheres
}

To explain what it means to use macroeconomic strategies in commercial lending decisions for regional banks we must look to not just federal regulatory lending policies, but also towards growth opportunities given idle resources within the demand for loanable funds. The term "regional banks" requires a definition beyond simply a zip code or a geographic area, as regional banks compete with the large consolidated banks that have enormous strength in their capacity for loanable funds. However, and most importantly, large banks lack flexibility and knowledge of local markets, which regional banks can use to their advantage. A few approaches that contribute to, and define, successful and effective lending policies (versus inflexible policies within large banks) are as follows:

First, when speaking of Macroeconomics as the aggregate activity for an economy, let us consider the macro view to be from 30,000 feet that incorporates the overall environment, (seeing the forest versus the trees). Whereas when we refer to Microeconomics or the micro view, think of it being from 500 feet where we can identify the sectors of an economy (or the individual trees in the forest).

Moreover, as a statistically significant example, let us consider the state of New Jersey, (NJ), which today contains $70 \%$ of the top 20 pharmaceutical companies worldwide. Many of the reasons why NJ targeted the Big Pharma sector was due to innovations in medical treatments that were accelerating this sector during the second half of the $20^{\text {th }}$ century. NJ became a "first mover" as a state government to offer incentives to businesses to relocate to their state, commencing in the 1960s. Hence, NJ provides a good example to the point of this discussion.

Banking is a highly regulated industry in terms of lending policies for commercial or residential property. However, all commercial banks, large or small, utilize federal fiscal policy guidelines to create a stimulus (demand) for their loanable funds that in turn can grow the microeconomic spheres within their geographical scope. (Microeconomic spheres are small geographic communities that are economically self-sustaining through their tax base.) As such, utilizing state and municipal bond offerings, as well as other financial instruments, $\mathrm{NJ}$ had access to a significant and growing supply of loanable funds that enabled regional banks to induce real estate developers to take on large suburban projects. In turn, with low-cost suburban housing developments becoming available, the state of $\mathrm{NJ}$ was able to accommodate the relocation and thus an employment base for the Big Pharma companies. These bond offerings created the capital to build highways and served as confirming signals to developers to seek out regional 
banks for loanable funds, whereas large institutional banks made loans to the corporations that served their nationwide and global needs, and were not focusing on smaller loans that were allocated to local state development infrastructure projects. Simultaneously at that time regional banks were busy participating in local politics, promoting bank products that allowed them to reap the early benefits of being "first movers" in the expansion strategies of NJ. Such was the case in the early 1960s.

Additionally, large multinational institutional lending has a long lead time, whereas regional banks are more flexible and faster in deciding upon loans. Moreover, being ingrained within NJ state programs, they were first to act on the market, leaving large multinational banks little choice but to acquire the regional banks to gain entry into the local market. Partly borne out of the expansionary post-war era of the 1950s where massproduced tract housing gave rise to the growth of regional banks, it also was NJ's strategy to induce Big Pharma companies to relocate within the state by offering significant tax abatements and employment assistance. Today, this strategy is a model for development agencies across all 50 states in America.

In the case of commercial real estate in the 1960s, NJ's state macroeconomic policy of attracting large pharmaceutical corporations utilizing large long-term tax abatements to relocate their Manufacturing and Distribution Centers was unique. Today, 50 years on, NJ boasts that it has 14 of the largest 20 pharmaceutical corporations in the world located in its home state. The envy of many states, and currently, we might note since the millennium (2000), the surrounding states have just begun to follow this strategy. With the inception of NJ's macroeconomic strategy, hundreds of thousands of jobs evolved. In turn, it created a large tax revenue base from a rapidly growing workforce that more than offset any loss of corporate tax revenues by fourfold through the multiplier effect. This point will be amplified later in this discussion.

Federal government lending regulations were eased post-WWII to accommodate growth as the US economy steadily continued on an upward slope. Such expansionary banking policies continued through the 1950s. However, as the banking industry grew into the mid-1960s there were several recessions, though none lasted beyond ten months. Nonetheless, during the 1960s the US experienced an expansion of nearly ten years. This expansion coincided with large investments within Big Pharma. The Polio epidemic and the discovery of penicillin had created an acceleration of research and development inside Big Pharma. This 10-year span was the nascent start of regional banks and developers who, together with utilizing municipal and state funding, changed commercial real estate lending. It was the start of modern-day banking that saw innovation in the marketing of loans as varied products to sell.

The workforce in this first suburban sphere of the 1960s spanned the first large commuter distances to and from these large pharmaceutical manufacturers and their corporate distribution campuses. By funding this infrastructure, the state of NJ considered the 
various distances and examined the opportunity costs of transportation. It was decided that a lower cost option was to build state highways to support their new suburban microsphere strategy rather than undertake longer-term and more costly public transportation systems, such as New York City, to serve populated suburban areas. Two multipliers took hold. First was the employment of workers to construct highways and municipal facilities such as sewers, road lighting, etc. and, second, the increased construction of tract housing that further employed workers. Both of these stimulated the tax revenue base, which added to the creditworthiness and funding of the municipal bonds. From a classical Macroeconomic definition of intermediate goods versus final goods, which are the only component of GDP, we see infrastructure as an intermediate product leading to final goods, i.e., homes. Thus, NJ saw tax revenues increase from an expanded workforce, infrastructure development, and from the builders of homes. These builders also benefitted from low-cost loans arising from the relatively low acquisition cost of rural farmlands as the highways extended further from urban centers.

Consequently, corporate relocation, driven by tax abatements and incentivized developers, gave rise to a new workforce base. The Schumpeter thesis was at work expanded infrastructure, such as highways reaching lower area land costs, thus yielding increased producer surplus for developers as they expanded to utilize rural farm acreage (figure 1), thereby creating lower residential housing costs and increasing consumer surplus (figure 2) to the new workforce.

Figure 1: Producer Surplus

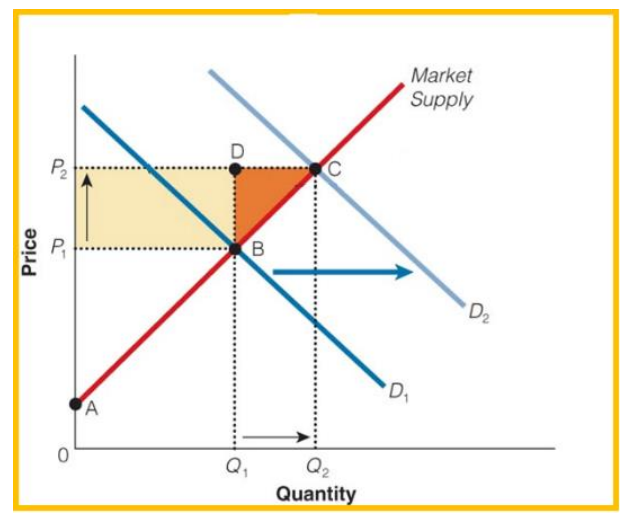

Figure 2: Consumer Surplus

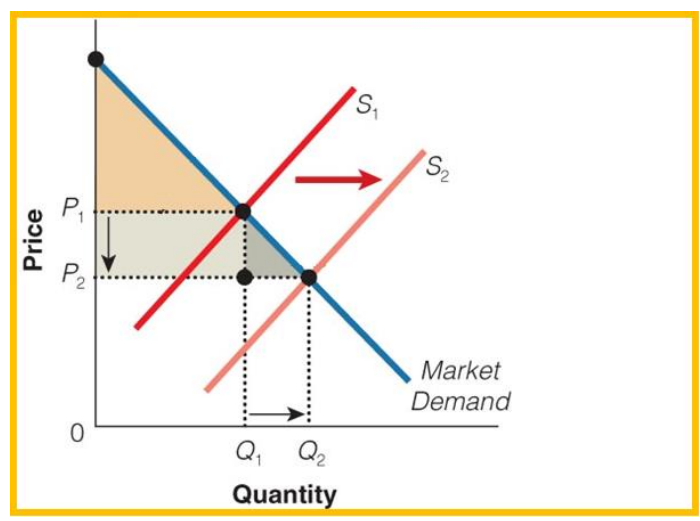

Such residential growth generated demand for commercial property for the businesses required to support the residents in these new communities (the beginning of our Microeconomic spheres). Residential demand now requires strip malls where they can shop for all of their necessities; supermarkets, laundromats, dry cleaners, repair centers, hardware stores, restaurants, et al. The most mundane of mundane are the requirements for any new suburban communities; Lawyers, title companies, child care, accountants, school teachers, service companies, etc. Macroeconomic policies to create more loanable funds in commercial real estate are now creating a new regional microeconomic sphere. 
This new microeconomic sphere, with its tax base, is now capable of self-financing these new municipalities for services such as fire, garbage, police, cultural centers, etc.

The key to creating the emergence of microeconomic spheres was the macroeconomic bank lending policies via lowering costs to the demand side (developers), thereby increasing their producer surplus and inducing them to innovate. The four factors of production in economics are land, labor, capital, and entrepreneurship (innovation and risk). Labor need not be discussed further as it is the implicit factor in the relocation of Big Pharma. The most significant to the emergence of a new microeconomic sphere are capital, land, and entrepreneurship. In our example, commercial loans were secured through the development itself, supported by state funding of the infrastructure. It follows that with commercial development comes further developing additions in a new microeconomic sphere, i.e., the demand for schools and their accompanying services. Commercial property development insures to meet the demand of this newly grown workforce that accompanied the relocated corporations. The commercial capital is predicted by the productivity of the business end product (tract housing development), unlike residential development, where the criteria for lending is individual income. Commercial lending offerings such as balloon notes and other financial vehicles are more likely to be facilitated through regional bank policies when space (vacant land) is available. Lastly, regional lending institutions have a different loan to principal ratios on existing properties sitting idle when there are previous sunk costs, particularly defaulted mortgages that sit on the bank's balance sheets. Revitalization of former malls or rework or reuse, re-zoning development constitutes the third leg of the productive factors for bank lending, i.e., Entrepreneurship (innovation). Such lending is a result of regional banks utilizing loans to facilitate economic gains at the margin. Where property already exists and sits vacant costs can be lower for the borrower as well as profits greater for the lender. These are the key opportunity factors of macro bank lending policies that can lead to the emergence of microeconomic spheres with regional acuity in its use of capital, land, and innovation of developers (Entrepreneurship).

The last part of this discussion leaves open how do certain elements, such as changing demographics, wages, taxation, population shifts, government leadership, economic activity, and in general how the business climate directly influences macroeconomic trends? In the end, an economy's workforce is dependent on its infrastructure (utilities, water, sewage, power, municipal services, total infrastructure, et al.). In a modern economy, as it relates to commerce previously discussed, it's mainly the public transportation systems, rail, and roads that play the largest part in a state's decision to implement macro lending policies assisting in developing new microeconomic spheres. New Jersey's use of macroeconomic tax policy decisions sought to grow their states GDP by increasing their tax revenue base via employment creation. NJ's macro lending policy created this by increasing its tax base to pay for new streets and traffic lights, road improvement, sewage, drainage, schools, and municipal services (police, refuse and fire). While this macro policy is common today in most states in America, NJ was 50 years 
ahead with its macro policy tax abatement formula to induce firms to relocate to their state, notwithstanding their size, large rural areas and proximity to New York City but because of its acumen in selecting Big Pharma as a specific growth sector.

An epilogue to the discussion of this article is how macro policies of banks on commercial lending will be radically different today in the $21^{\text {st }}$ century. Macro policies of the future must address the cost of living and the geography of skilled labor. Firms in the tech or health sectors (non-polluting positive externality industries), no longer consider moving from one state to another solely based on tax benefits. Today more and more corporations in the tech sphere base relocation primarily on finding an emerging or existing qualified workforce. The discussion of macro lending policies for regional banks on the commercial property remains unchanged, but it's the types of employment today has changed. Most corporations locate in cluster cities as a key to meeting the demand for skilled labor. Skilled workforces have shifted to the urban centers where higher education is more affordable as they do not carry the expense of the large sprawling campus universities. Commercial lending must now consider changing demographics. Career opportunities are proliferating for an educated and skilled workforce (SIC, career opportunities are $72 \%$ higher in urban centers). However, College graduates in their late twenties seeking to begin families will be swayed by a lower cost of living (housing, education, transportation, schools, etc.). New suburban microeconomic spheres can continue to grow in NJ. However, increased traffic and congestion now requires a $21^{\text {st }}$ century a Macro lending policy to invest in the building of true hi-speed rapid transit that can move at 300 miles per hour, spanning 75 to 100 miles in 20 minutes to attract the new skilled tech workforce required in urban centers. Those skilled workers will still, if not more so, require to live in lower cost suburban communities as urban centers become increasingly unaffordable. An inflation calculator using NYC and San Francisco, both urban tech centers, respectively, NYC apartment rental prices (per \$100) in the same period went from $\$ 100$ to $\$ 174$ and San Francisco $\$ 100$ to $\$ 148$. As this urban workforce transformation emerges, regional banks engaged in the new $21^{\text {st }}$-century macro lending policies, supporting the demand for new innovative microeconomic spheres, will capture the $21^{\text {st }}$-century corporation for future growth.

\section{Sources:}

https://www.smarsh.com/solutions/industries/government https://patheon.com/commercial-manufacturing-services https://www.adp.com/spark/articles/2018/06/corporate-relocation-managing-costs-benefitsand-risks.aspx https://www.cengage.com/discipline-economics/ https://www.bayareamarketreports.com http://www.in2013dollars.com/Rent-of-primary-residence/price-inflation 